Journal of the Electrochemical Society, Vol. 149, No. 6, 2002, pp. B239-B247.

ISSN: 0013-4651

DOI: $10.1149 / 1.1471546$

http://www.electrochem.org/

http://www.ecsdl.org/getpdf/servlet/GetPDFServlet?filetype=pdf\&id=JESOAN00014900000600B239000001\&idty

pe $=$ cvips\&prog $=$ normal

(C) The Electrochemical Society, Inc. 2002. All rights reserved. Except as provided under U.S. copyright law, this work may not be reproduced, resold, distributed, or modified without the express permission of The Electrochemical Society (ECS). The archival version of this work was published in Journal of the Electrochemical Society, Vol. 149, No. 6, 2002, pp. B239-B247.

\title{
A Study of Corrosion and Pitting Initiation of AA2024-T3 Using Atomic Force Microscopy
}

\author{
P. Leblanc* and G. S. Frankel* \\ Fontana Corrosion Center, Department of Materials Science and Engineering, The Ohio State University, \\ Columbus, Ohio \\ * Electrochemical Society Active Member.
}

The corrosion behavior of a population of microstructural inclusions in AA2024-T3 and the interactions between individual inclusions were investigated using atomic force microscopy-based techniques. The results showed that $\mathrm{Al}-\mathrm{Cu}-\mathrm{Fe}-\mathrm{Mn}$ intermetallic particles were cathodic in nature and interacted strongly with their surroundings. For large exposed areas, it was found that pitting initiated at a few $\mathrm{Al}_{2} \mathrm{CuMg}$ particles, which became active upon film breakdown even though scanning Kelvin probe force microscopy measurements in air showed they were noble with respect to the matrix prior to the exposure. The size and location of the cathodic regions proved to be critical issues. Accelerated matrix dissolution took place for exposed areas containing a large area fraction of Al$\mathrm{Cu}-\mathrm{Fe}-\mathrm{Mn}$ inclusions. The location of the cathodic sites had a strong influence on the local chemistry of the environment and controlled the corrosion behavior of the surface. Potentiodynamic measurements made using a remote cathode indicated no copper redeposition around the pit and on the matrix, in contrast with open-circuit exposure, where active cathodic inclusions modify the local $\mathrm{pH}$. It was also found that pits generated at $\mathrm{Al}_{2} \mathrm{CuMg}$ inclusions became ennobled as a result of $\mathrm{Cu}$ enrichment but did not become active cathodic sites.

Investigations into the corrosion behavior of AA2024-T3 have shown that this aluminum alloy is susceptible to pitting and inter-granular corrosion in sodium chloride environments. ${ }^{1-3}$ In general, the susceptibility of aluminum-copper alloys to corrosion increases with copper content, an effect that may be attributed to the formation of galvanic cells at microstructural elements (copper-rich inter-metallics $v s$. matrix or $\mathrm{Cu}$-depleted grain boundary zones) or by the enhanced catalytic activity at those intermetallics or $\mathrm{Cu}$-enriched regions on the alloy surface. ${ }^{4-8}$ Galvanic relationships among discrete microstructural elements of AA2024 can be inferred from a list of corrosion potentials of intermetallic phases of the Al-Cu-Mg-Fe-Mn-Si system in $\mathrm{NaCl}$ under various environmental conditions. The data indicate, for instance, that $\mathrm{Al}-\mathrm{Cu}-\mathrm{Fe}-\mathrm{Mn}$ phases are noble with respect to the $\mathrm{Al}$ matrix and should act as cathodes, whereas $\mathrm{Al}_{2} \mathrm{CuMg}$ inclusions generally considered as S-phase particles should be more active than the matrix and behave as preferential initiation sites for localized corrosion. The situation in commercial alloys is complicated by the existence of a large variety of composition and size distribution of inclusions. ${ }^{10,11}$ Furthermore, the presence of air-formed passive oxide films on the alloy surface adds to the complexity. In the as-polished condition, S-phase particles in AA2024-T3 exhibited higher Volta potentials than the bulk matrix and only became active when the surface film responsible for the high potential was removed during extended immersion at open circuit in chloride solution. ${ }^{12}$ 
Corrosion reactions and rates are often determined from microscopy at specific sites randomly selected from among a large number on the corroded specimen surface or using data (e.g., potential or current) from large-scale experiments with exposed areas in the square centimeter range. New techniques aimed at investigating local changes in properties at the micrometer or nanometer range offer additional insight to the mechanism of localized corrosion. ${ }^{13-16}$ Using a microelectrochemical cell, Suter and Alkire were able to isolate and document the behavior of areas on AA2024-T3 with diameter as small as $20 \mu \mathrm{m}$. They found that the breakdown potential increased as the measured area decreased, and that pitting of Al-Cu-Fe-Mn particles occurred at higher values than at $\mathrm{Al}_{2} \mathrm{CuMg}$ inclusions. Areas containing no visible inclusions did not pit until very high potentials. In general, the pitting potential of bulk (large) samples is fixed by the most active inclusions.

Atomic force microscopy (AFM) is a powerful technique for the analysis of surface structures at a very high lateral resolution. Techniques associated with the AFM have been used to generate considerable understanding of the corrosion behavior of AA2024. ${ }^{13-15,17}$ Scanning Kelvin probe force microscopy (SKPFM) was used to produce maps of the Volta potential distribution across surfaces of AA2024-T3 in air. ${ }^{12-14}$ This technique provided clear evidence regarding shape, position, compositional inhomogeneities, and local practical nobility of intermetallic compounds with submicrometer resolution. Surface modifications after exposure to $\mathrm{NaCl}$ solutions were clearly revealed. The ability of the AFM to image a surface while it is immersed in a solution has provided a very interesting approach for the in situ characterization of electrochemical processes. In particular, in situ AFM scratching has been used to locally stimulate the depassivation of the protective oxide or hydroxide film on $\mathrm{Al}$ in solution. Under certain conditions, pitting was initiated by AFM scratching of the surface oxide on AA2024-T3 in $\mathrm{NaCl}$ solutions. The behavior depended on the exact location and nature of the microstructure that was scratched. Scratching of $\mathrm{Al}_{2} \mathrm{CuMg}$ inclusions in solution resulted in the immediate dissolution of the particle, while dichromate additions resulted in the formation of a much harder and more stable film.

In this paper, the corrosion mechanism and pit initiation of AA2024-T3 in NaCl solutions were investigated using these AFM-based techniques in conjunction with a new micromasking method. The first part of this study describes results from large exposed areas $\left(1 \mathrm{~cm}^{2}\right)$. The time evolution of the Volta potential was determined for various experimental conditions and pitting events were documented. In the second part of this study, AFM measurements were performed at well-characterized individual inclusions during initial stages of attack. A masking method was developed to selectively expose to an electrolyte square areas ("windows") as small as $2 \times 2$ $\mu \mathrm{m}$. This method allows the study of microstructural elements at a smaller scale than previously possible. ${ }^{12,16}$ Galvanic interactions among discrete microstructural inclusions of different size or nature can be studied by opening up two or more windows at the same time.

\section{Experimental}

Disk samples (1.5 cm diam, $2 \mathrm{~mm}$ thick) were cut from an AA2024-T3 sheet (nominal composition 3.8-4.9\% Cu, 1.2-1.8\% Mg, 0.3-0.9\% Mn, 0.5\% Fe, 0.5\% Si, 0.25\% Zn, 0.1\% Cr, $0.05 \% \mathrm{Ti}$, balance $\mathrm{Al}$ ). A nonaqueous lubricating slurry (Blue Lube from Struers) was used during the surface preparation (grinding and polishing). The AA2024-T3 disks were mechanically ground with successively finer $\mathrm{SiC}$ paper through 1200 grit and polished with 6, 3, and $1 \mu \mathrm{m}$ diamond paste. Prior to study, samples were cleaned ultrasonically with ethyl alcohol. 
Pure $\mathrm{Ni}$ and $\mathrm{Cu}$ samples (99.99\% rod) were ground through 1200 grit SiC paper in Blue Lube and then ultrasonically cleaned in ethyl alcohol.

Surface sputtering of AA2024-T3 samples was performed using a PHI-Perkin/Elmer 680 scanning Auger nanoprobe system with a field emission electron gun. The sputtering rate was calibrated with respect to a $\mathrm{SiO}_{2} / \mathrm{Si}$ reference sample and was $16 \mathrm{~nm} / \mathrm{min}\left(2 \mathrm{kV} \mathrm{Ar}{ }^{+}\right.$at $\left.1 \mu \mathrm{A}\right)$.

Mapping of topography and Volta potential (by SKPFM) at the sample surfaces was performed using either a Nanoscope III AFM or a Dimension 3000 AFM (both are commercial microscopes from Digital Instruments). In situ AFM scratching and potentiodynamic studies were performed in the small fluid cell of the Nanoscope III. These techniques have been described elsewhere. ${ }^{12-14}$ Volta potential measurements were performed in air using conductive $\mathrm{Pt} / \mathrm{Ir}$-coated silicon tips. Volta potentials are reported $v \mathrm{~s}$. the potential measured on a pure $\mathrm{Ni}$ sample, which served as a calibration standard. Ni was chosen as a reference because it was found to have a stable Volta potential. Topographic maps were performed in situ or in air.

Because of AFM scanner limitations, topographic and Volta potential distribution maps had to be restricted to areas of the AA2024 surface smaller than $100 \times 100 \mu \mathrm{m}$. However, large size areas $\left(1 \mathrm{~cm}^{2}\right)$ of AA2024 were exposed to a drop $(\sim 0.5 \mathrm{~mL})$ of $\mathrm{NaCl}$ solution or $\mathrm{NaCl}$ solution containing $10^{-4} \mathrm{M} \mathrm{Na}_{2} \mathrm{Cr}_{2} \mathrm{O}_{7}$. Solutions were prepared with reagent-grade chemicals and deionized water. The evolution of open-circuit potential (OCP) was monitored during the exposure. After a given exposure time, the sample was quickly rinsed with deionized water, dried in air, and the exact same area on the sample was documented by AFM. The cycle of exposure and documentation was repeated.

Contact-mode AFM scratching tests were performed in the small fluid cell of the Nanoscope III microscope using commercially available Si probes. Tip pressure on the sample surface is associated with a set-point voltage control. This set-point voltage can be instantaneously increased or reduced. Unless mentioned otherwise, the typical set-point voltage used for scratching was $0.5 \mathrm{~V}$

Electrochemical measurements were performed on samples mounted in the electrochemical cell of the Nanoscope III microscope, which has a volume of approximately 0.1 $\mathrm{mL}$. Electrolyte was pumped through the cell from a reservoir at a rate of $10 \mathrm{~mL} / \mathrm{h}$ using a peristaltic pump. A saturated calomel reference electrode (SCE) was located just downstream of the cell and a Pt-mesh counter electrode was placed in the waste beaker. A Gamry potentiostat was used for electrochemical measurements, which were performed in the electrochemical fluid cell of the AFM. Because of the large ohmic resistance associated with the remote placement of the reference electrode (RE), IR compensation by the current interrupt method was used. All the potentials are reported vs. the SCE electrode. A sweep rate of $0.05 \mathrm{mV} / \mathrm{s}$ was chosen for potentiodynamic scans. During some scans an area of the sample was rastered in contact-mode by the AFM tip. Owing to the slow sweep rate, rastering of the entire square area occurred within $25 \mathrm{mV}$

Polymeric ink from a retouching pen (Kimoto Pake Pen) was used to mask an area of interest. A drop of ethanol was used as a solvent to dilute and spread the ink over the sample, forming a layer with a thickness of about $150 \mathrm{~nm}$. Previously well-characterized inclusions were still visible underneath the transparent film using the video camera in the AFM. One or more windows in the ink film, each containing specific regions of the microstructure such as individual inclusions, were opened up by scratching off the ink in air with an AFM tip (Fig. 1a). Diamond-coated silicon tips from Digital Instruments were used for this process. Two passes of contact-mode scratching (frequency $1 \mathrm{~Hz}$, set point $2 \mathrm{~V}$ ) were enough to expose the underlying 
surface (Fig. 1b). Exposure experiments were conducted by depositing a drop of solution $(\sim 0.5$ $\mathrm{mL}$ ) on the surface. After immersion, the sample was rinsed in water and the ink was removed by rinsing with ethanol. The ink protected covered areas from corrosion attack for at least $4 \mathrm{~h}$. The topographic and potential

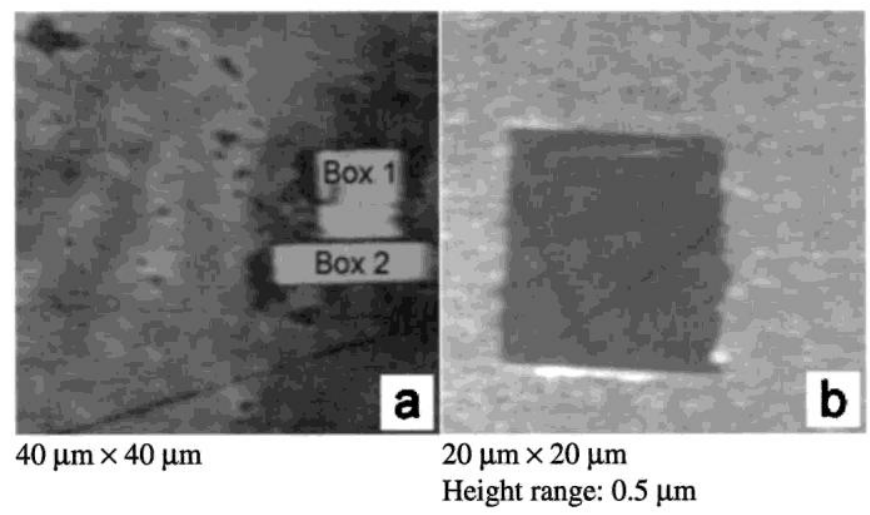

Figure 1. (a) Video capture of two openings in the ink film, and (b) AFM contact-mode topographic image of $10 \times$ $10 \mu \mathrm{m}$ opening into masking coating. features of the AA2024-T3 surface were not altered by deposition and removal of the ink layer.

\section{Results and Discussion}

Experiments with large exposed areas $\left(1 \mathrm{~cm}^{2}\right)$. - SKPFM characterization.-AA2024-T3 contains many intermetallic inclusions $\left(>200,000 / \mathrm{cm}^{2}\right.$, covering $4 \%$ of the area) ${ }^{11}$ The total area of $\mathrm{Al}_{2} \mathrm{CuMg}$ particles is three times larger than the total area of $\mathrm{Al}-\mathrm{Cu}-\mathrm{Fe}-\mathrm{Mn}$ particles. Figure 2 shows the topography and Volta potential maps of an area of an as-polished AA2024-T3 sample. The few raised regions visible in the topographic map (left image) are associated with inclusions protruding from the surface because of a lower rate of polishing. The numerous bright regions in the Volta potential map (right image) are associated with inclusions, which were analyzed by energy-dispersive spectroscopy (EDS). All intermetallic particles exhibit a Volta potential higher than the matrix. The region contains large bulky generic Al-Cu-Fe-Mn particles (particles 1-4), small Al-Cu-Fe-Mn particles (particles 5-7), which are visible on the topographic map, and smaller and rounder $\mathrm{Al}_{2} \mathrm{CuMg}$ inclusions. Some $\mathrm{Al}_{2} \mathrm{CuMg}$ particles with a diameter of $1 \mu \mathrm{m}$ or less are also revealed. The $\mathrm{Al}-\mathrm{Cu}-\mathrm{Fe}-\mathrm{Mn}$ intermetallic compounds are brighter than the $\mathrm{Al}_{2} \mathrm{CuMg}$ particles on the potential map and thus have a higher Volta potential. The $\mathrm{Al}_{2} \mathrm{CuMg}$ particles cannot be distinguished in the topographic map. Loss of material by corrosion during polishing may balance the slower rate of material removal resulting from the increased hardness of these particles. Two holes are present on the as-polished surface and are not associated with any potential contrast. Pit-like holes were frequently found on the surface despite the nonaqueous nature of the polishing slurry. These holes could result from the dissolution of $\mathrm{S}$ phases, pull-out of particles during polishing, or polishing indents left by $\mathrm{SiC}$ particles.

The nobility in air of the $\mathrm{Al}_{2} \mathrm{CuMg}$ particles with respect to the matrix is in disagreement with the results of Buchheit, who reported that the OCP of bulk $\mathrm{Al}_{2} \mathrm{CuMg}$ was about $100 \mathrm{mV}$ more active than the matrix. Schmutz and Frankel ${ }^{13}$ have attributed the high Volta potential of 


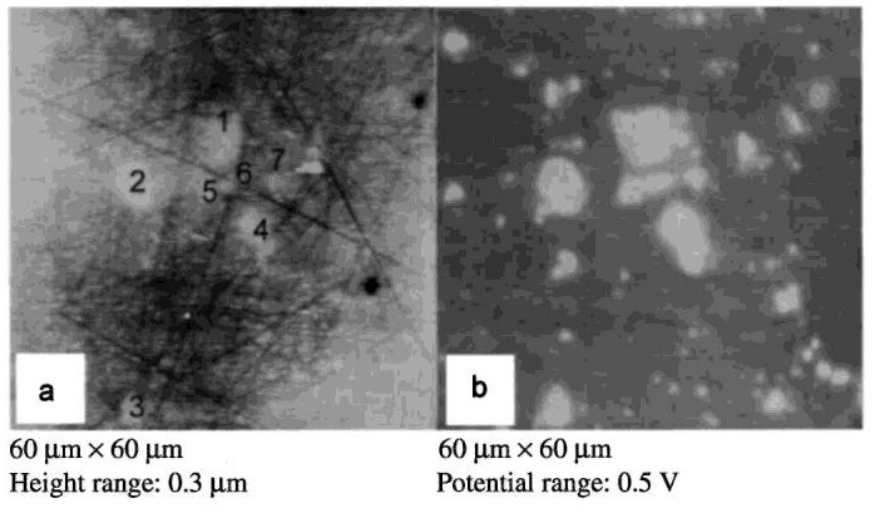

Figure 2. (a) Topography and (b) SKPFM Volta potential map of an as-polished AA2024-T3 alloy surface. Particles 1-7 are Al-Cu-Fe-Mn inclusions.

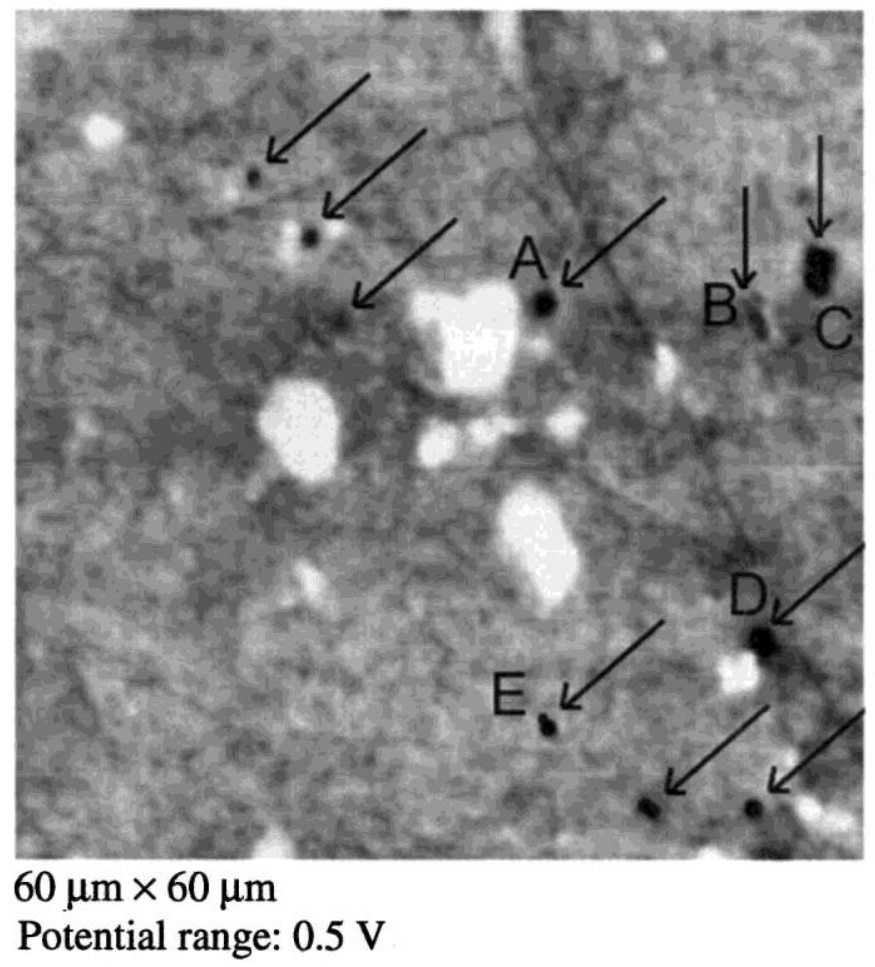

Figure 3. SKPFM Volta potential map of AA2024-T3 after partial removal of the surface film. The top 1/3 of the thickness of the oxide on an as-polished sample (see Fig. 2) was sputtered in an AES apparatus. The arrows point to the particles whose potentials decreased as a result of sputtering.

$\mathrm{Al}_{2} \mathrm{CuMg}$ particles measured in air to the presence of an oxide film of altered composition generated during the polishing steps. As-polished samples were subjected to sputter etching in an Auger electron spectroscopy (AES) instrument until the surface oxide film was partially or 
totally removed, then removed from vacuum and exposed to air, and subsequently immersed in sodium chloride solution. The $\mathrm{O}$ signal was used as a tracer of the oxide film during sputter etching. The effect of this sputter etching and subsequent reformation of oxide in air on the Volta potential of the different phases and their corrosion susceptibility was then investigated. Figure 3 shows the Volta potential map generated on the surface of the sample shown in Fig. 2, but after sputter etching through about one-third of the thickness of the surface oxide film. The topographic image (not shown) is very comparable to the as-polished condition, shown in Fig. 2a. However, the Volta potential map in Fig. 3 reveals major differences from the as-polished state. The potential contrast between all inclusions and the matrix is decreased by about $100 \mathrm{mV}$ and does not change during oxide reformation in air (for up to 1 week). This indicates that a film resulting from the polishing steps is not simply deposited on the surface but deeply interacts with the underlying matrix and inclusion. The contours of the bright spots in the Volta potential map are more clearly defined and scratches can be seen on the matrix. More interestingly, some previously noble $\mathrm{Al}_{2} \mathrm{CuMg}$ inclusions have become more active and appear as dark spots in the picture. But only a few of the $\mathrm{Al}_{2} \mathrm{CuMg}$ phases (indicated by black arrows) have turned dark, indicating that composition differences exist between inclusions of a same category. Suter ${ }^{17}$ found that inclusions of nominally the same composition showed a wide range of corrosion behavior. The pitting potential associated with $\mathrm{S}$-phase particles varied over a range of $550 \mathrm{mV}$ in that work.

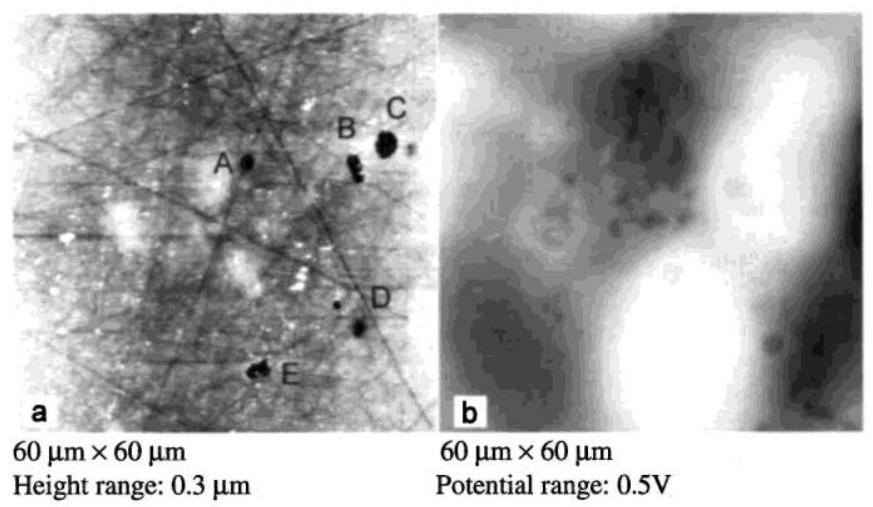

Figure 4. (a) Topography and (b) SKPFM Volta potential map of the sputtered AA2024-T3 sample (3 nm) after exposure to $0.5 \mathrm{M} \mathrm{NaCl}$ for $30 \mathrm{~min}$. Pits formed at particles $\mathrm{Al}_{2} \mathrm{CuMg}$ A-E. same category. Suter ${ }^{17}$ found that inclusions of nominally the same composition showed a wide range of corrosion behavior. The pitting potential associated with S-phase particles varied over a range of $550 \mathrm{mV}$ in that work.

Other areas on the same sample were sputter etched to different depths. Regions etched $12 \mathrm{~nm}$ (complete removal of the surface oxide) or only $1 \mathrm{~nm}$ did not exhibit any particles that had reversed nobility relative to the matrix such that they turned dark in the Volta potential map. This observation of a critical depth within the oxide at which S-phase particles reverse polarity has been made on several different samples. However, the depth for this phenomenon was not completely reproducible and varied over 3-6 $\mathrm{nm}$. The differences may be related to uncontrollable aspects of the polishing procedure. 
Exposure to $\mathrm{NaCl}$ solution.-After being documented in air with the AFM, the partially sputtered sample $(3 \mathrm{~nm})$ was exposed to $0.5 \mathrm{M} \mathrm{NaCl}$ for $30 \mathrm{~min}$. As shown in Fig. 4a, the first pits on the surface formed at some but not all of the $\mathrm{Al}_{2} \mathrm{CuMg}$ inclusions that exhibited lower Volta potential after sputtering (particles A-E). The pit shapes are similar in size and shape to the Volta potential features shown in Fig. 3, indicating that the $\mathrm{Al}_{2} \mathrm{CuMg}$ inclusions have been completely reacted. Neither the matrix, nor the other inclusions (those that retained a relatively high Volta potential) were attacked during the $30 \mathrm{~min}$ exposure. The Volta potential contrast in Fig. $4 \mathrm{~b}$ decreased to such an extent that the particles were no longer visible in the potential map, and poorly defined areas of higher potential are the sole features. It is interesting that nonsputtered samples will also develop pits at $\mathrm{Al}_{2} \mathrm{CuMg}$ particles during a $30 \mathrm{~min}$ exposure to $0.5 \mathrm{M} \mathrm{NaCl}$, even though all of these particles on an as-polished surface exhibit a relatively high potential. Previous work had shown that pits formed at $\mathrm{Al}_{2} \mathrm{CuMg}$ particles in AA2024-T3 after about 120 min in $0.1 \mathrm{M} \mathrm{NaCl}$, which was the time for the Volta potential of the particles to approach that of the matrix. AFM scratching in $0.01 \mathrm{M} \mathrm{NaCl}$ resulted in immediate attack of the $\mathrm{Al}_{2} \mathrm{CuMg}$ particles. ${ }^{13}$ Sputter etching is another method, like long-term open circuit exposure or in situ scratching, that results in regions of low potential that are susceptible to attack.

The evolution with time of the Volta potentials of different regions in as-polished AA2024-T3 samples (area of $1 \mathrm{~cm}^{2}$ ) exposed to $0.5 \mathrm{M} \mathrm{NaCl}$ is represented in Fig. 5. With time, the potential of all noncorroding areas converge to a common value. In contrast, corroded $\mathrm{Al}_{2} \mathrm{CuMg}$ particles leave behind a pit with a very noble potential. The measured Volta potential at the pits is comparable with the Volta potential of pure metallic $\mathrm{Cu}$ after immersion in $0.5 \mathrm{M}$ $\mathrm{NaCl}$ solution. Copper deposits around inclusions have been often reported in the literature. $6,11,18,19$ The Volta potential of the matrix steadily increases with immersion time, in agreement with the OCP measurements, as discussed later. Identical observations were made in $0.01 \mathrm{M}$ $\mathrm{NaCl}$ solutions. In all exposure tests, pits formed and were always found at $\mathrm{Al}_{2} \mathrm{CuMg}$ particles.

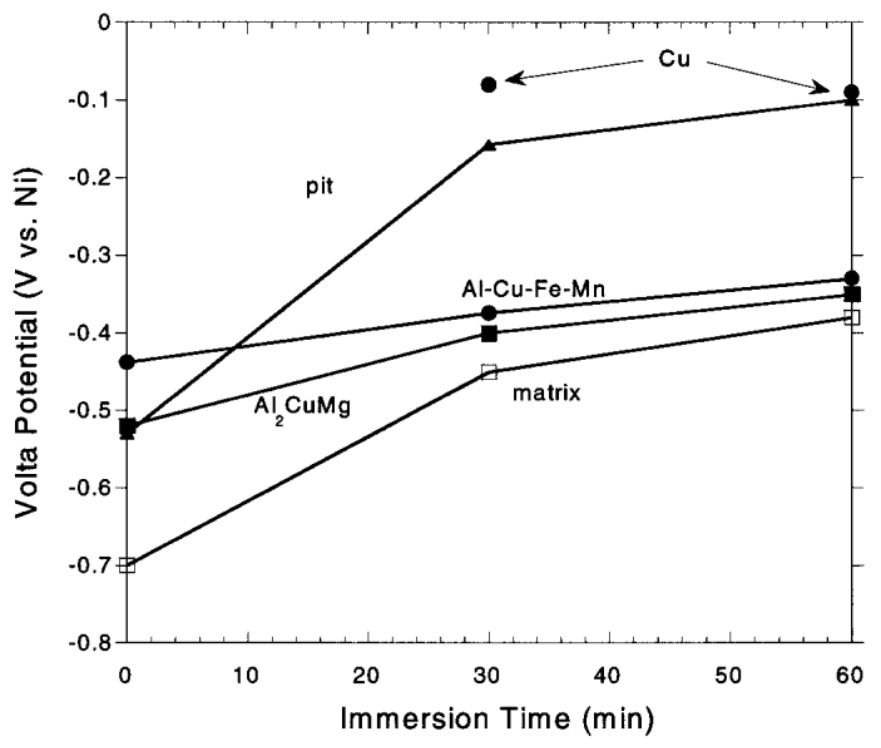

Figure 5. Volta potential change of pits, uncorroded matrix, and uncorroded intermetallic particles in AA2024-T3 following immersion in $0.5 \mathrm{M} \mathrm{NaCl}$ for different periods of time. Volta potential of $\mathrm{Cu}$ is given for comparison. 
$\mathrm{Al}-\mathrm{Cu}-\mathrm{Fe}-\mathrm{Mn}$ inclusions and the matrix were never attacked at this early time of the corrosion process. The Volta potential of the matrix increased progressively with immersion time, and there was no significant potential difference with the uncorroded intermetallics after $30 \mathrm{~min}$. The potential measured at pits was not as high in $0.01 \mathrm{M} \mathrm{NaCl}$ as in $0.5 \mathrm{M} \mathrm{NaCl}$, perhaps because thick corrosion products devoid of $\mathrm{Cu}$ tend to cover the pits and do not exhibit particularly high intrinsic Volta potentials.

Exposure to solution containing dichromate ions.-AA2024-T3 samples were exposed to $\mathrm{NaCl}$ solutions containing dichromate ions. Dichromate ions are usually incorporated to coatings or added to the electrolyte in order to increase the corrosion resistance of $\mathrm{Al}$ alloys. Indeed, the addition of dilute dichromate to $0.5 \mathrm{M} \mathrm{NaCl}$ electrolytes altered the corrosion behavior. Figure 6a shows the topography and surface potential distribution of another as-polished sample prior to testing. No localized corrosion was detected after exposure to $0.5 \mathrm{M} \mathrm{NaCl}+10^{-4} \mathrm{M} \mathrm{Na}_{2} \mathrm{Cr}_{2} \mathrm{O}_{7}$ for 240 min (Fig. 6b). The two large dark regions in the topography map are only scanning artifacts. The contrast in the potential image stayed high even after the prolonged exposure, in contrast to the behavior in the chloride solution with no dichromate. The Volta potentials of the intermetallic particles and the matrix increased only slightly with time, suggesting some very moderate corrosion and little copper deposition, and the difference in potential between them remained constant (Fig. 7). The Volta potential of pure Al (99.99\%) exposed to the same chromate-containing solution remained unchanged after up to $4 \mathrm{~h}$ of exposure. AES studies have shown that a chromium-rich $\left(\mathrm{Cr}^{\mathrm{III}}-\mathrm{Cr}^{\mathrm{VI}}\right)$ film forms on the entire surface of AA2024-T3, but preferentially on the $\mathrm{Al}_{2} \mathrm{CuMg}$ inclusions, when chromate is added to the sodium chloride solution. ${ }^{19,20}$ It was suggested that chromate strongly inhibits magnesium dissolution and prevents copper redeposition on the bulk matrix, which is in agreement with our data.

The OCPs of AA2024-T3 samples exposed to different solutions can be compared to the Volta potential of the matrix measured in air after exposure (Fig. 8). The graphs are quite similar. The steady-state OCP in $0.5 \mathrm{M} \mathrm{NaCl}+10^{-4} \mathrm{M} \mathrm{Na}_{2} \mathrm{Cr}_{2} \mathrm{O}_{7}$ reached a plateau about $50 \mathrm{mV}$ lower than the pitting potential determined from an anodic polarization curve. The OCP in $0.5 \mathrm{M} \mathrm{NaCl}$ drifted rapidly to the pitting potential and the Volta potential of the matrix was quickly pinned at the potential of active corrosion sites. These results indicate that the pitting potential is fixed by the most active inclusions. The Volta potential of the matrix measured in air appears to successfully track surface modifications resulting from exposure to solution and is well correlated to the OCP of a large size $\left(1 \mathrm{~cm}^{2}\right)$ sample.

Polarization measurements of an AA2024-T3 disk $\left(1 \mathrm{~cm}^{2}\right)$ in $0.5 \mathrm{M} \mathrm{NaCl}+10^{-4} \mathrm{M}$ $\mathrm{Na}_{2} \mathrm{Cr}_{2} \mathrm{O}_{7}$ were performed in the commercial AFM fluid cell with the AFM probe mounted, but the AFM tip never was in contact with the sample surface during the experiment (the probe was raised about $1 \mu \mathrm{m}$ above the surface). An increase in current at about $-0.6 \mathrm{~V} \mathrm{SCE}$ was associated with pit initiation, and erratic jumps in potential for $i>10 \mu \mathrm{A} / \mathrm{cm}^{2}$ were caused by a loss of ionic conductivity in the capillary-like inlet and outlet ports of the fluid cell when hydrogen bubbles were released from pits. Real-time observations of the surface with a CCD (charge-coupled device) video camera clearly indicated that the hydrogen bubbles never formed in the area underneath the noncontacting AFM probe $(50 \times 100 \mu \mathrm{m})$ and originated from pits in other parts of the sample. AFM analysis after the scan confirmed that this particular area did not contain any pits. This experiment was replicated three times with identical results. It is possible that the geometry of the fluid cell establishes flow conditions under and around the AFM probe 

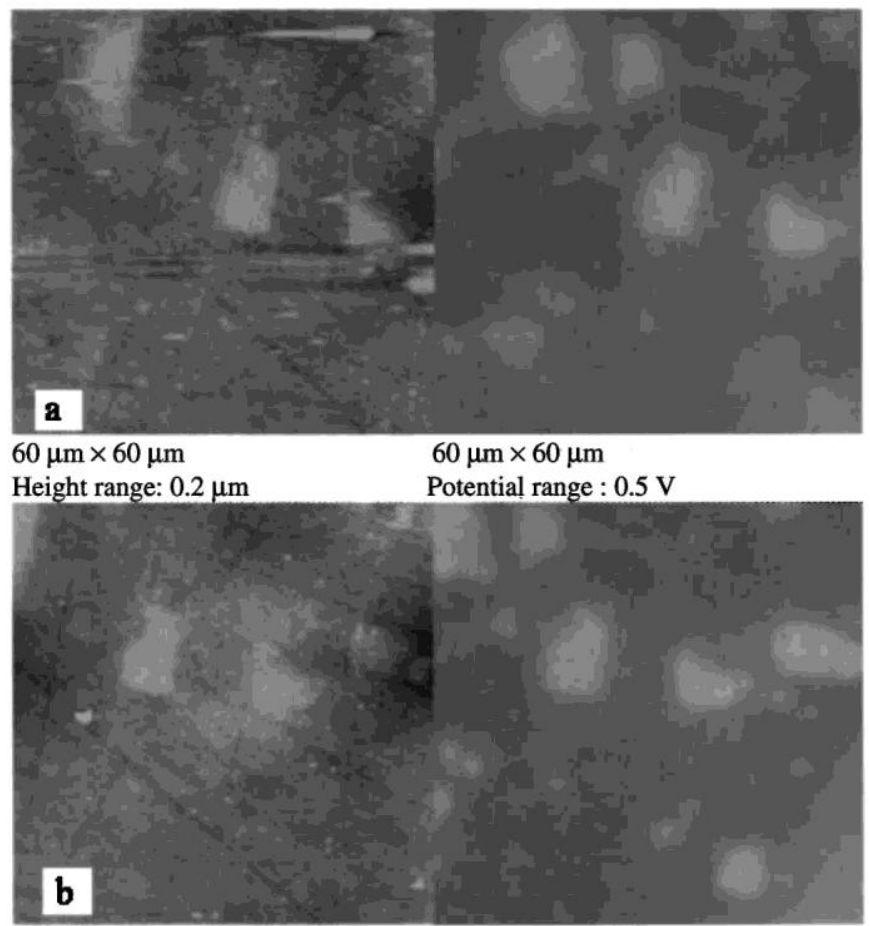

$60 \mu \mathrm{m} \times 60 \mu \mathrm{m} \quad 60 \mu \mathrm{m} \times 60 \mu \mathrm{m}$

Height range: $0.2 \mu \mathrm{m} \quad$ Potential range : $0.5 \mathrm{~V}$

Figure 6. Topography and Volta potential map of the AA2024-T3 sample (a) as-polished and (b) after 240 min in $0.5 \mathrm{M} \mathrm{NaCl}+10^{-4} \mathrm{M} \mathrm{Na}_{2} \mathrm{Cr}_{2} \mathrm{O}_{7}$.

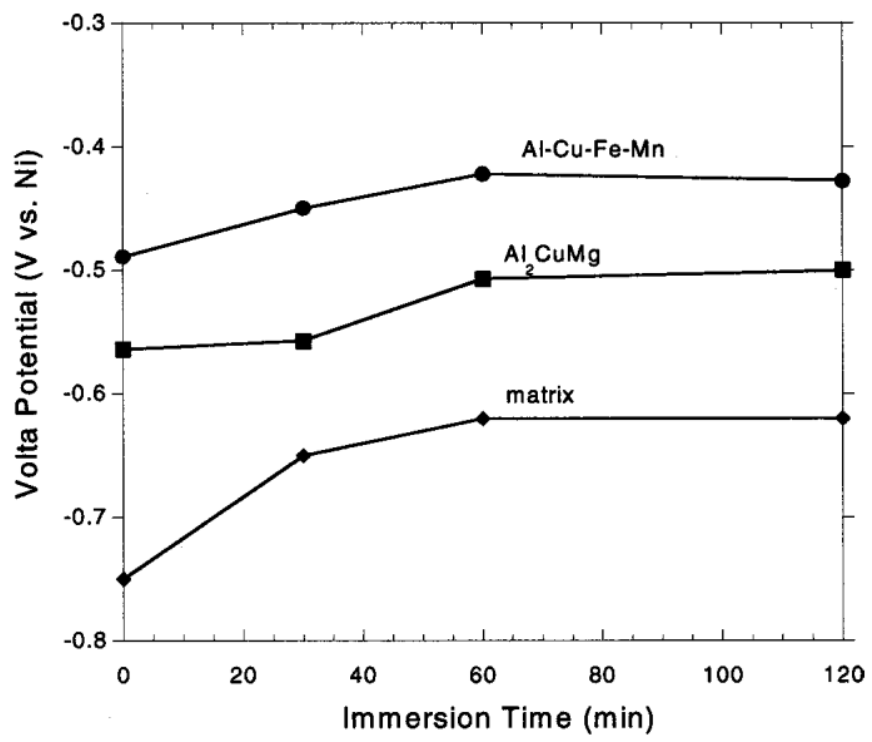

Figure 7. Volta potential change of matrix and intermetallic particles of AA2024-T3 in $0.5 \mathrm{M} \mathrm{NaCl}+10^{-4} \mathrm{M}$ $\mathrm{Na}_{2} \mathrm{Cr}_{2} \mathrm{O}_{7}$. 

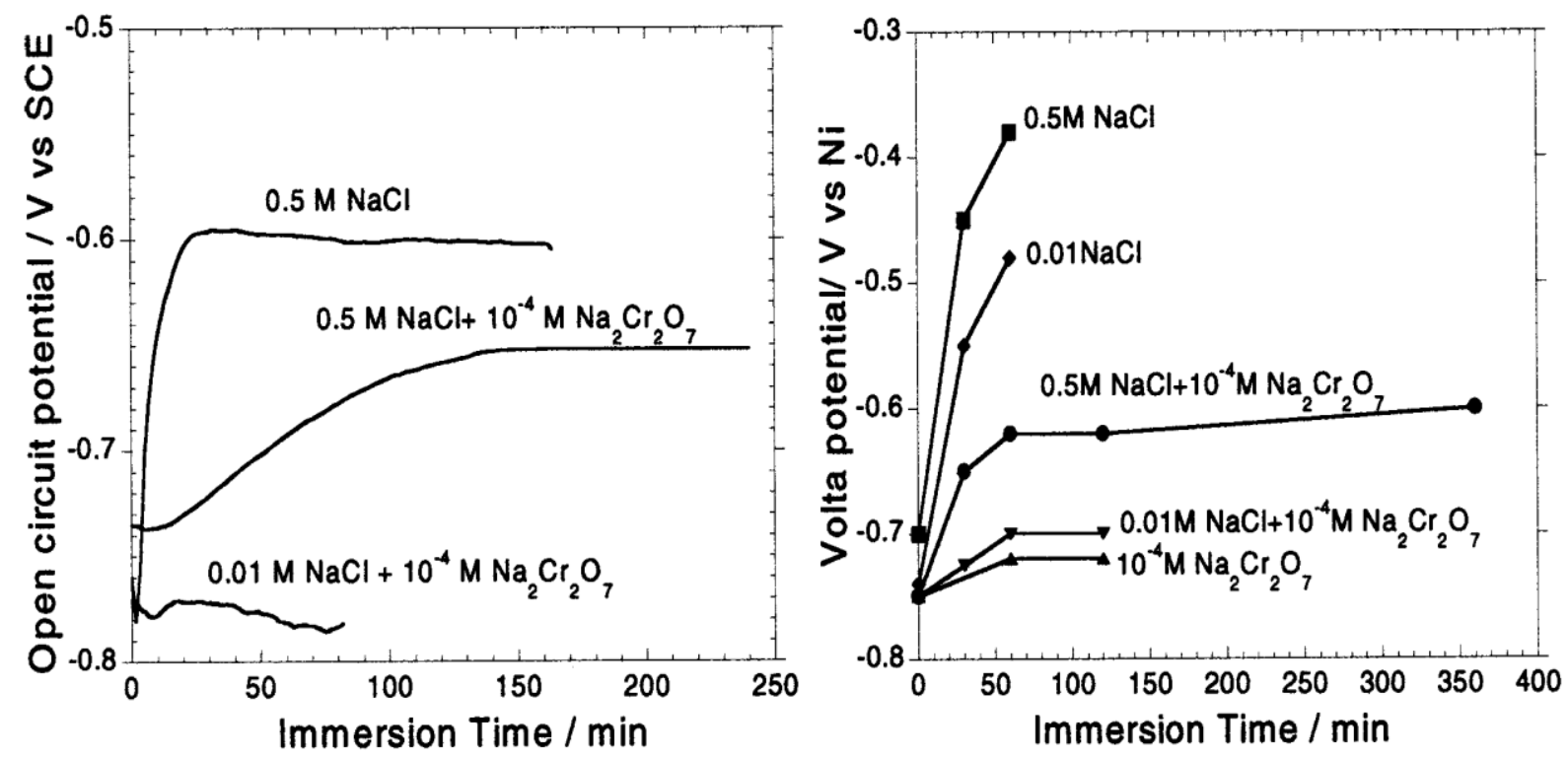

Figure 8. Evolution of (left) OCP and (right) Volta potential of AA2024-T3 matrix with time for AA 2024 immersed in various electrolytes.

so that the environment there is less aggressive.

Similar potentiodynamic experiments were performed in $0.5 \mathrm{MNaCl}+10^{-4} \mathrm{M} \mathrm{Na}_{2} \mathrm{Cr}_{2} \mathrm{O}_{7}$ on AA2024-T3 samples $\left(1 \mathrm{~cm}^{2}\right)$ with the tip scanning the surface in contact mode ("scratching") at a low set-point voltage of $0.5 \mathrm{~V}$. Scratching was started when the potential was $-0.70 \mathrm{~V}$ SCE. The potentiodynamic sweep rate was $0.05 \mathrm{mV} / \mathrm{s}$ so that one full scratching pass was completed in $25 \mathrm{mV}$ (i.e., $8 \mathrm{~min}$ ). In these conditions, sustained hydrogen evolution started at the AFM tip between -0.65 and $-0.63 \mathrm{~V} \mathrm{SCE}$, slightly below the potential for pit initiation of an unscratched sample. Scratching of the surface acted as a trigger for corrosion in a region that would not have otherwise pitted. At this point, bubbles forced the tip off the surface and generated considerable noise in the electrochemical measurement. Figure 9a shows a $60 \times 60 \mu \mathrm{m}$ region following polishing and prior to the electrochemical testing in $0.5 \mathrm{MNaCl}+10^{-4} \mathrm{M}$ $\mathrm{Na}_{2} \mathrm{Cr}_{2} \mathrm{O}_{7}$. A large Al-Cu-Fe-Mn inclusion (particle 1) can be seen in the topographic image and smaller $\mathrm{Al}_{2} \mathrm{CuMg}$ intermetallics are revealed in the potential map. The region in the box was rastered during the potentiodynamic polarization scan. Figure $9 \mathrm{~b}$ shows the topography of the rastered area after the onset of hydrogen evolution at the tip, just before the experiment was terminated $(E=-643 \mathrm{mV} \mathrm{SCE})$. A pit initiated at the periphery of particle 1 and propagated in the adjacent matrix. Pitting never formed at $\mathrm{Al}_{2} \mathrm{CuMg}$ inclusions during scanning in the dilute dichromate-containing solution, which is a reproducible observation from several experiments. Pits preferentially initiated at the matrix/ Al-Cu-Fe-Mn interface where local anodic and cathodic sites can be simultaneously activated.

Experiments with small exposed areas. -Multiple inclusions. -The Volta potential map of an as-polished $60 \times 60 \mu \mathrm{m}$ area is shown in Fig. 10a, where three large $\mathrm{Al}-\mathrm{Cu}-\mathrm{Fe}-\mathrm{Mn}$ inclusions labeled 1,2 , and 3 are clearly distinguished. The other particles are $\mathrm{Al}_{2} \mathrm{CuMg}$ inclusions (S- 
phases). Particles 1, 2, and 3 comprise about $5 \%$ of this investigated area and the S-phase particles comprise about $1.5 \%$. This $60 \times 60 \mu \mathrm{m}$ area was opened up through an ink layer and exposed to $1 \mathrm{~mL}$ of $0.5 \mathrm{M} \mathrm{NaCl}$ for $60 \mathrm{~min}$. A video image of the surface shows that pitting occurred in the exposed area while neighboring areas covered by the ink remained
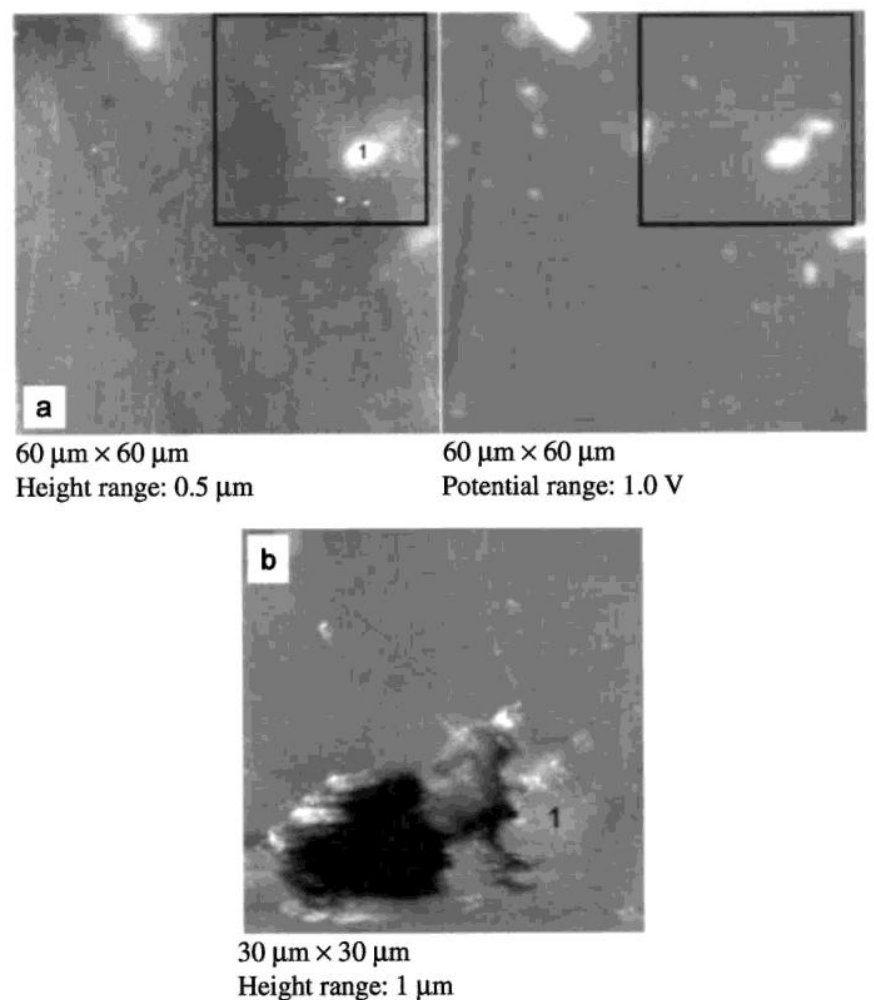

Figure 9. (a) Topography and Volta potential map of as-polished AA2024-T3 disk and (b) topographic image of the scratched area (box in Fig. 9a) after the first pit formed at $0.5 \mathrm{~V}$ set point. $0.5 \mathrm{M} \mathrm{NaCl}+10^{-4} \mathrm{M} \mathrm{Na}_{2} \mathrm{Cr}_{2} \mathrm{O}_{7},-643 \mathrm{mV}$ vs. SCE. 


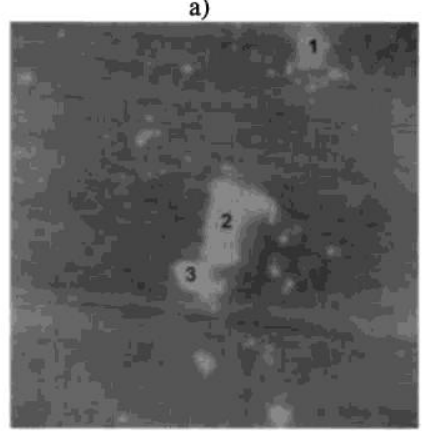

$60 \mu \mathrm{m} \times 60 \mu \mathrm{m}$

Potential range: $0.5 \mathrm{~V}$

c)

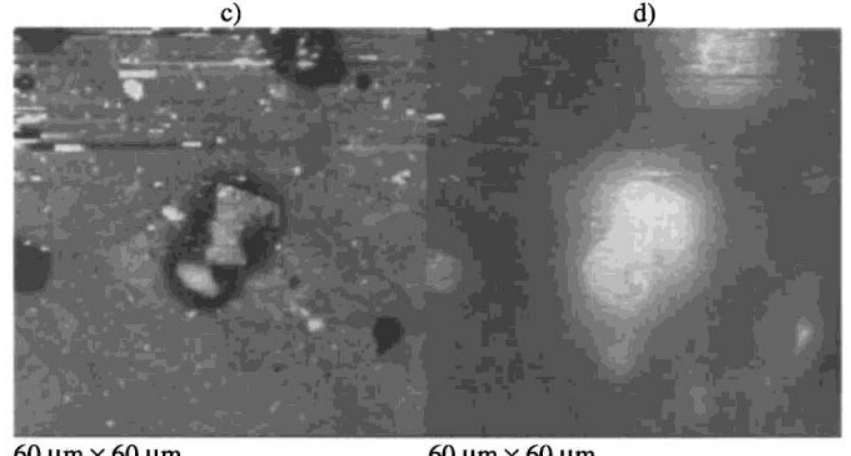

$60 \mu \mathrm{m} \times 60 \mu \mathrm{m}$

Height range: $0.5 \mu \mathrm{m}$ b)

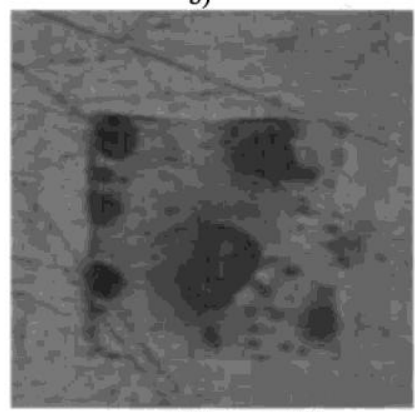

$100 \mu \mathrm{m} \times 100 \mu \mathrm{m}$

d)

$\mu \mathrm{m} \times 60 \mu \mathrm{m}$

Potential range: $1.0 \mathrm{~V}$

Figure 10. (a) Volta potential map of $60 \times 60 \mu \mathrm{m}$ area of an as-polished AA2024-T3 sample. Particles 1-3 are Al$\mathrm{Cu}-\mathrm{Fe}-\mathrm{Mn}$ inclusions. (b) Video image of the surface after exposure to $0.5 \mathrm{M} \mathrm{NaCl}$ for 60 min, showing the corroded $60 \times 60 \mu \mathrm{m}$ area as a corroded square. (c) Topographic map of $60 \times 60 \mu \mathrm{m}$ area after exposure. (d) Volta potential map of $60 \times 60 \mu \mathrm{m}$ area after exposure.

unattacked, Fig. 10b. AFM characterization of the exposed area after exposure indicated that pits in the topography map (Fig. 10c) are associated with bright spots in the potential map (Fig 10d), suggesting $\mathrm{Cu}$ enrichment. Some new features that were not observed after 60 min open circuit exposure of large areas $\left(>1 \mathrm{~cm}^{2}\right)$ are now present in this figure. There is extensive dissolution of the matrix at the periphery of particles 1,2, and 3 instead of steady growth of pits at S-phase particles. This can be explained by the cumulative area ratio of particles 1,2 , and 3 to that of the other inclusions, which in this case was ten times higher than the typical area ratio of $\mathrm{Al}-\mathrm{Cu}-\mathrm{Fe}-$ $\mathrm{Mn}$ to $\mathrm{Al}_{2} \mathrm{CuMg}$ particles on large surfaces of AA2024-T3. When the most active S-phase inclusions were fully reacted and $\mathrm{Cu}$ remnants left behind (possibly becoming cathodic sites), the corrosion process apparently turned to other weak areas, such as the matrix. The perimeter of the Fe-rich particles was a favored site for matrix attack. This suggests that deep trenches might form around $\mathrm{Al}-\mathrm{Cu}-\mathrm{Fe}-\mathrm{Mn}$ inclusions or at grain boundaries in large-scale experiments once all of the most active inclusions are consumed.

$\mathrm{Al}-\mathrm{Cu}-\mathrm{Fe}-\mathrm{Mn}$.-The ability to open windows in the ink-masking layer at desired locations permitted studies of the reactivity of isolated particles. A $3 \times 3 \mu \mathrm{m}$ window was opened in the middle of a large Al-Cu-Fe-Mn particle $(>20 \mu \mathrm{m})$ such that only this particle was exposed. After a $2 \mathrm{~h}$ immersion in $0.5 \mathrm{M} \mathrm{NaCl}$ there was no significant change in roughness or in the Volta potential of the particle, indicating a robust intrinsic corrosion resistance of this particle. 
However, when the exposed area contained a whole particle and some surrounding matrix, accelerated dissolution of the matrix took place, as seen in Fig. 11. Pitting started at the interface and quickly propagated into the matrix away from the particle. This is clear evidence that

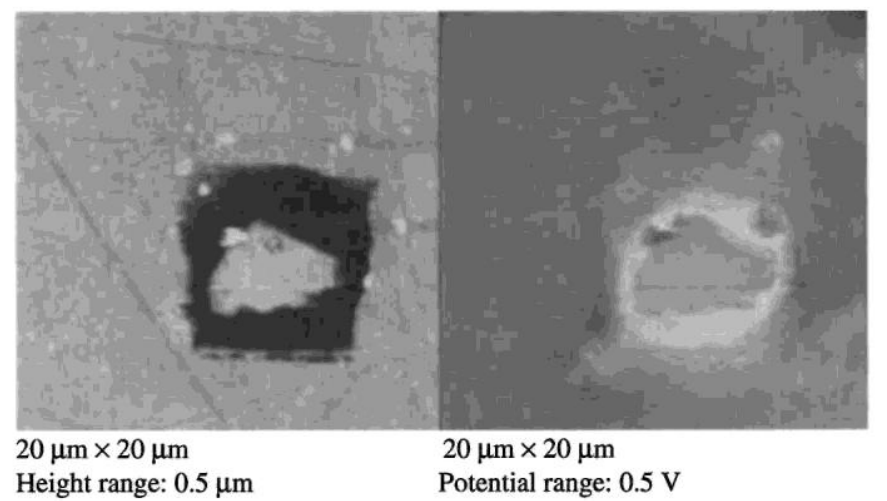

Figure 11. (left) Topography and (right) Volta potential map of $\mathrm{Al}-\mathrm{Cu}-\mathrm{Fe}-\mathrm{Mn}$ inclusion exposed to $0.5 \mathrm{M} \mathrm{NaCl}$ for 60 min.

$\mathrm{Al}-\mathrm{Cu}-\mathrm{Fe}-\mathrm{Mn}$ inclusions in AA2024-T3 are efficient cathodic regions and can drive corrosion reactions, not only at active $\mathrm{Al}_{2} \mathrm{CuMg}$ particles but also in the matrix. Similar observations have been made in Al-6061 alloys. ${ }^{8}$ The extent of matrix dissolution after $60 \mathrm{~min}$ in $0.5 \mathrm{M} \mathrm{NaCl}$ is shown as a function of the initial area percent of Al-Cu-Fe-Mn inclusions in Fig. 12. Matrix dissolution data are normalized for $1 \mu \mathrm{xm}^{2}$ of the cathodic inclusion. For a low area fraction of $\mathrm{Al}-\mathrm{Cu}-\mathrm{Fe}-\mathrm{Mn}$ inclusions, limited matrix dissolution occurs and $\mathrm{Al}_{2} \mathrm{CuMg}$ inclusions are preferential attack sites. As the area ratio of the cathodic region increases, the extent of matrix dissolution increases.

$\mathrm{Al}_{2} \mathrm{CuMg}$. - It was not possible to position a window on S-phase particles because they are too small for accurate tip placement and scratching. Instead, windows were positioned on regions containing only S-phase particles and surrounding matrix, with no Al-Cu-Fe-Mn particles. The white box in Fig. 13a indicates the location of the exposed area of an as-polished sample that contained three visible $\mathrm{Al}_{2} \mathrm{CuMg}$ particles $(\mathrm{A}, \mathrm{B}$, and $\mathrm{C}$ ). A pit-like hole associated with a high potential is present in the lower right part of the picture. This hole formed during polishing and was covered by the mask, so it was not exposed to the solution. After 120 min exposure at open circuit to $0.5 \mathrm{M} \mathrm{NaCl}$, none of the particles (A, B, or C) pitted, Fig. 13b. They did not react because there was no simultaneous exposure of $\mathrm{Al}-\mathrm{Cu}-\mathrm{Fe}-\mathrm{Mn}$ particles, which act as efficient

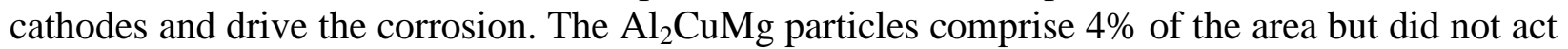
as cathodes to drive corrosion of the matrix phase. 


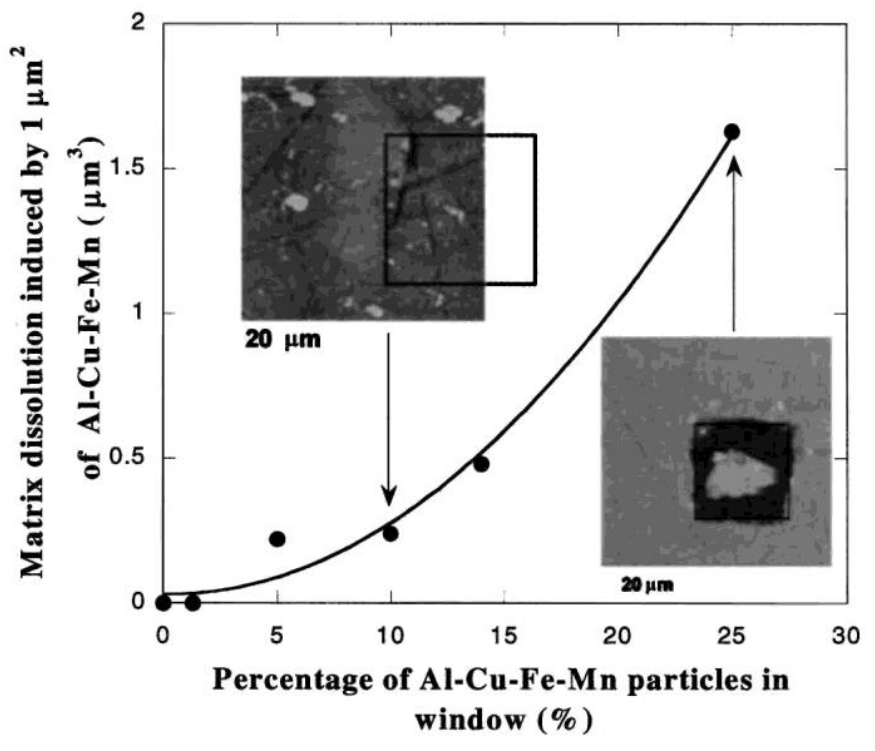

Figure 12. Effect of area fraction of Al-Cu-Fe-Mn inclusions in exposed window on extent of matrix dissolution during $60 \mathrm{~min}$ in $0.5 \mathrm{M} \mathrm{NaCl}$. 

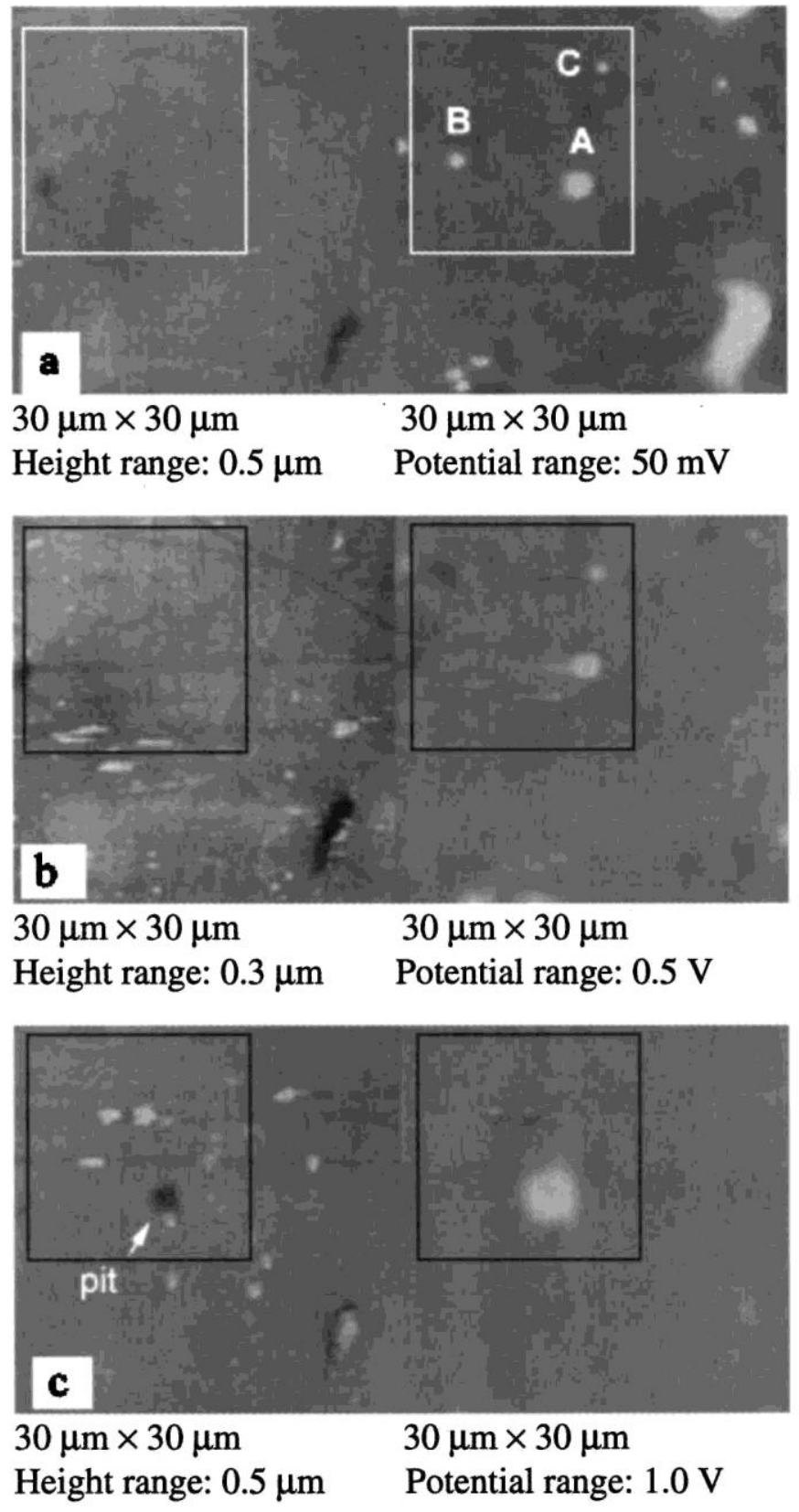

Figure 13. (left) Topography and (right) Volta potential map of AA2024-T3 (a) as-polished, (b) after exposure 120 min in $0.5 \mathrm{M} \mathrm{NaCl}$ at OCP, and (c) same as (b) +20 min polarization at $-600 \mathrm{mV} v s$. SCE in $0.5 \mathrm{M} \mathrm{NaCl}$. Exposed areas are in boxes.

A mask was then reapplied to the sample and the area shown by the box in Fig. 13b was opened up again. The sample was mounted in the fluid cell of the AFM and a potential of -600 $\mathrm{mV} \mathrm{SCE}$ was applied for $20 \mathrm{~min}$ in $0.5 \mathrm{M} \mathrm{NaCl}$ in order to test if the particles would be attacked under controlled anodic conditions. Inclusion A dissolved and left behind a $350 \mathrm{~nm}$ deep pit, Fig. 13c. The potential map suggests that the bottom of the pit is covered with $\mathrm{Cu}$ and attack did not spread around the inclusion. It is also very interesting that the Volta potential of the matrix did 
not change during the course of the experiment. These observations are in contrast with observations made at open circuit, where the high-potential region spread far beyond the boundaries of the attacked $\mathrm{Al}_{2} \mathrm{CuMg}$ particles. During potentiostatic experiments, reduction reactions took place principally at the remote counter electrode and less at Al-Cu-Fe-Mn particles. As a consequence, there was less increase in $\mathrm{pH}$ near these particles and therefore no visible dealloying.

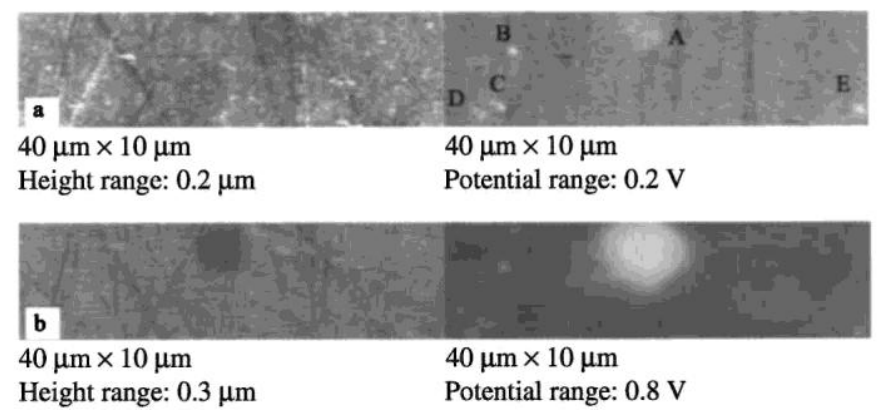

Figure 14. (left) Topography and (right) Volta potential map of $40 \times 10 \mu \mathrm{m}$ window of AA2024-T3 (a) as-polished and (b) after exposure $1 \mathrm{~h} 0.5 \mathrm{M} \mathrm{NaCl}$. Particles A-E are $\mathrm{Al}_{2} \mathrm{CuMg}$ inclusions.

A pit did form at $\mathrm{Al}_{2} \mathrm{CuMg}$ particles in some windows devoid of $\mathrm{Al}-\mathrm{Cu}-\mathrm{Fe}-\mathrm{Mn}$ particles and exposed to $0.5 \mathrm{M} \mathrm{NaCl}$. The $\mathrm{Al}_{2} \mathrm{CuMg}$ particles that reacted under this condition were larger than average $(4-5 \mu \mathrm{m})$ and exhibited a relatively low initial Volta potential in air, i.e., only 20-50 $\mathrm{mV}$ positive to the matrix. Figure $14 \mathrm{a}$ shows a $40 \times 10 \mu \mathrm{m}$ window before exposure containing such an active inclusion. $\mathrm{Al}_{2} \mathrm{CuMg}$ particles (A-E) are barely visible in the potential map unless the potential scale is magnified (notice the scale of the image). They represent about 1-2\% of the exposed area. Upon exposure of this area to $0.5 \mathrm{M} \mathrm{NaCl}$ for $1 \mathrm{~h}$, the large $\mathrm{Al}_{2} \mathrm{CuMg}$ inclusion (A) corroded, but the attack was restricted to the particle itself and did not spread to the adjacent matrix or other inclusions. Furthermore, the "pit" that formed at the particle was actually only a shallow depression, about $50 \mathrm{~nm}$ deep. The potential map in Fig. 14b shows that corrosion products resulting from the anodic dissolution are located at the bottom of the pit and did not redeposit away from the particle. Furthermore, it is interesting that once the particle reacted and formed a Cu-rich corrosion product, no further corrosion occurred in the window. It is not clear why this $\mathrm{Cu}$-rich corrosion product did not become a cathodic site, as might be expected given its high potential. If the product was electrically disconnected from the matrix, it would not have generated a signal in the SKPFM. It is possible that the product was covered with a protective layer that was washed away when the sample was removed from solution and rinsed.

Dual exposure.-Interactions between different particles were evaluated in experiments with two windows exposed in the protective ink film. The procedure is best described with the help of Fig. 1a. Ink was deposited on the whole sample and the first window ("box 1') was opened up to reveal an intermetallic particle. The size of the window depended on the type of particle. The sample was exposed to a $0.5 \mathrm{M} \mathrm{NaCl}$ solution $(1 \mathrm{~mL})$ for $60 \mathrm{~min}$ or $0.01 \mathrm{M}$ $\mathrm{Na}_{2} \mathrm{Cr}_{2} \mathrm{O}_{7}(1 \mathrm{~mL})$ for $30 \mathrm{~min}$, quickly rinsed with water, and dried. The second window ("box 2 ") was then opened up to reveal another region of the sample. The area containing both boxes 
was then exposed to $0.5 \mathrm{M} \mathrm{NaCl}$. Table I shows the results of combinations performed using this dual exposure.

The first experiments were controls to examine previous observations. In experiment 1 , the first window $(4 \times 4 \mu \mathrm{m})$ exposing part of an Al-Cu-Fe-Mn particle $(>20 \mu \mathrm{m}$ in size $)$ was an active cathodic site that promoted pitting at various $\mathrm{Al}_{2} \mathrm{CuMg}$ particles in the second window (20 $\times 20 \mu \mathrm{m}$ ) during exposure to chloride, as expected. The topographic and surface potential maps of the Al-Cu-Fe-Mn area in window 1 after exposure did not exhibit any roughening or copper enrichment. Experiment 2 tested the simultaneous exposure of two areas that contained only

Table I. Summary of the observed corrosion behavior in dual-exposure experiments.

\begin{tabular}{|c|c|c|c|c|c|c|}
\hline & $\begin{array}{l}\text { Particle in } \\
\text { window no. } 1\end{array}$ & $\begin{array}{l}\text { Window } 1 \\
\text { exposure }\end{array}$ & $\begin{array}{l}\text { Particle in } \\
\text { window no. } 2\end{array}$ & $\begin{array}{l}\text { Dual-window } \\
\text { exposure }\end{array}$ & Window 1:window 2 area ratio & Results \\
\hline 1 & $\mathrm{Al}-\mathrm{Cu}-\mathrm{Fe}-\mathrm{Mn}$ & $\mathrm{NaCl}$ & $\begin{array}{l}\mathrm{Al}_{2} \mathrm{CuMg}+ \\
\text { matrix }\end{array}$ & $0.5 \mathrm{M} \mathrm{NaCl}$ & $1 / 25$ & $\begin{array}{l}\text { Pits in no. } 2 \text { at } \\
\mathrm{Al}_{2} \mathrm{CuMg}\end{array}$ \\
\hline 2 & $\mathrm{Al}-\mathrm{Cu}-\mathrm{Fe}-\mathrm{Mn}$ & $\mathrm{NaCl}$ & $\mathrm{Al}-\mathrm{Cu}-\mathrm{Fe}-\mathrm{Mn}$ & $0.5 \mathrm{M} \mathrm{NaCl}$ & $1 / 1$ & No pit \\
\hline 3 & $\begin{array}{l}\text { Large } \\
\mathrm{Al}_{2} \mathrm{CuMg}+\text { matrix }\end{array}$ & $\mathrm{NaCl}$ & $\begin{array}{l}\mathrm{Al}_{2} \mathrm{CuMg} \\
+ \text { matrix }\end{array}$ & $0.5 \mathrm{M} \mathrm{NaCl}$ & $1 / 4$ & $\begin{array}{l}\text { Pit in no. } 1 \\
\text { No pit in no. } 2\end{array}$ \\
\hline 4 & $\mathrm{Al}-\mathrm{Cu}-\mathrm{Fe}-\mathrm{Mn}$ & $\mathrm{Na}_{2} \mathrm{Cr}_{2} \mathrm{O}_{7}$ & $\begin{array}{l}\mathrm{Al}-\mathrm{Cu}-\mathrm{Fe}-\mathrm{Mn}+ \\
\mathrm{Al}_{2} \mathrm{CuMg}+ \\
\text { matrix }\end{array}$ & $0.5 \mathrm{M} \mathrm{NaCl}$ & $1 / 10$ & $\begin{array}{l}\text { Pits in no. } 2 \text { at } \\
\mathrm{Al}_{2} \mathrm{CuMg} \\
\text { and around } \mathrm{Al}-\mathrm{Cu}-\mathrm{Fe}-\mathrm{Mn}\end{array}$ \\
\hline 5 & $\mathrm{Al}_{2} \mathrm{CuMg}+$ matrix & $\mathrm{Na}_{2} \mathrm{Cr}_{2} \mathrm{O}_{7}$ & $\mathrm{Al}-\mathrm{Cu}-\mathrm{Fe}-\mathrm{Mn}$ & $0.5 \mathrm{M} \mathrm{NaCl}$ & $2 / 1$ & No pit \\
\hline 6 & $\begin{array}{l}\text { Al-Cu-Fe-Mn } \\
+ \text { matrix }\end{array}$ & $\mathrm{Na}_{2} \mathrm{Cr}_{2} \mathrm{O}_{7}$ & $\begin{array}{l}\mathrm{Al}_{2} \mathrm{CuMg} \\
\text { + matrix }\end{array}$ & $0.5 \mathrm{M} \mathrm{NaCl}$ & $1 / 1$ & No pit \\
\hline 7 & $\mathrm{Al}-\mathrm{Cu}-\mathrm{Fe}-\mathrm{Mn}$ & $\mathrm{Na}_{2} \mathrm{Cr}_{2} \mathrm{O}_{7}$ & $\begin{array}{l}\mathrm{Al}_{2} \mathrm{CuMg}+ \\
\text { matrix }\end{array}$ & $0.5 \mathrm{M} \mathrm{NaCl}$ & $1 / 5$ & No pit \\
\hline
\end{tabular}

regions of $\mathrm{Al}-\mathrm{Cu}-\mathrm{Fe}-\mathrm{Mn}$ particles. No sign of attack was detected even in the presence of another $\mathrm{Al}-\mathrm{Cu}-\mathrm{Fe}-\mathrm{Mn}$ inclusion. In experiment 3 , a large $\mathrm{Al}_{2} \mathrm{CuMg}$ particle in box 1 spontaneously reacted without the presence of $\mathrm{Al}-\mathrm{Cu}-\mathrm{Fe}-\mathrm{Mn}$ cathodic sites during the initial exposure to $0.5 \mathrm{M}$ $\mathrm{NaCl}$. However, the $\mathrm{Cu}$-rich corrosion product layer did not trigger pits at small S-phase particles in the adjacent window 2 during the subsequent exposure to the $\mathrm{NaCl}$ solution. This supports the observation that reacted $\mathrm{Al}_{2} \mathrm{CuMg}$ particles do not switch to cathodic sites.

The next set of experiments clarifies the influence of prior exposure to chromate on the subsequent behavior of AA2024-T3 in $0.5 \mathrm{M} \mathrm{NaCl}$. In experiment 4 , an area $(5 \times 5 \mu \mathrm{m})$ containing only $\mathrm{Al}-\mathrm{Cu}-\mathrm{Fe}-\mathrm{Mn}$ was treated in $0.01 \mathrm{MNa}_{2} \mathrm{Cr}_{2} \mathrm{O}_{7}$. This treated area was then exposed to $1 \mathrm{~mL}$ of $0.5 \mathrm{M} \mathrm{NaCl}$ with another area $(16 \times 16 \mu \mathrm{m})$ containing matrix, Al-Cu-Fe-Mn particles, and S-phase particles. The second area corroded, as would have been expected had it not been exposed to a chromate-treated area; pitting was found at the S-phase particles and the matrix around the Al-Cu-Fe-Mn particles was attacked. The chromate-treated area had no apparent effect on the behavior of the untreated second area. The observation might be only valid for the specific conditions that were used, but it raises the question if chromate-treated $\mathrm{Al}-\mathrm{Cu}-\mathrm{Fe}-$ Mn particles release chromate in a self-healing mechanism of inhibition.

In experiment 5, a window containing $\mathrm{Al}_{2} \mathrm{CuMg}$ particles and matrix $(6 \times 6 \mu \mathrm{m})$ was exposed to a dichromate solution and then immersed in $0.5 \mathrm{M} \mathrm{NaCl}$ in the presence of an area 
exposing a portion of an Al-Cu-Fe-Mn particle $(4 \times 4 \mu \mathrm{m})$, which should have been an active cathodic site. No attack of any type was observed. It is possible that the Cr-containing film formed as a result of the dichromate exposure released to passivate the $\mathrm{Al}-\mathrm{Cu}-\mathrm{Fe}-\mathrm{Mn}$ area. However, it is more likely that the film acted as a protective barrier on the matrix and $\mathrm{Al}_{2} \mathrm{CuMg}$ inclusions, inhibiting breakdown.

In experiments 6 and 7, windows containing $\mathrm{Al}-\mathrm{Cu}-\mathrm{Fe}-\mathrm{Mn}$ particles were exposed to dichromate solution and then exposed to chloride solution along with untreated windows that contained only matrix and S-phase particles, with no Al-Cu-Fe-Mn particles. Again no attack was found. If the $\mathrm{Al}-\mathrm{Cu}-\mathrm{Fe}-\mathrm{Mn}$ region is not first treated with dichromate, the second area is attacked upon exposure to chloride (experiment 1). Again it is possible that chromate could be released from the $\mathrm{Al}-\mathrm{Cu}-\mathrm{Fe}-\mathrm{Mn}$ particles, but experiment 4 suggested that this did not occur. Instead, these experiments indicate that the dichromate treatment passivates the $\mathrm{Al}-\mathrm{Cu}-\mathrm{Fe}-\mathrm{Mn}$ particles, essentially acting as a cathodic inhibitor for AA2024-T3 in addition to the protection it provides to the anodic matrix and $\mathrm{Al}_{2} \mathrm{CuMg}$ regions, as shown in experiment 5 .

The results bring to light some interesting effects of individual $\mathrm{Al}-\mathrm{Cu}-\mathrm{Fe}-\mathrm{Mn}$ particles on the corrosion behavior of the bulk matrix or $\mathrm{Al}_{2} \mathrm{CuMg}$ particles inAA2024-T3. When $\mathrm{Al}-\mathrm{Cu}-\mathrm{Fe}-$ Mn particles were active (no protective chromate surface film preventing cathodic reactions), pitting was observed at S-phases and/or in the bulk matrix. Contact-mode scratching in $0.01 \mathrm{M}$ $\mathrm{NaCl}$ even resulted in the immediate dissolution of S-phase particles in contact with the tip. In the presence of a dichromate film, both anodic dissolution and cathodic reactions were prevented. This combined effect might partially explain why it is so difficult to find an alternative to $\mathrm{Cr}(\mathrm{VI})$ with comparable protection efficiency. However, corrosion of AA2024-T3 in the presence of dilute dichromate ions could be triggered by the progressive local disruption of the protective oxide film on the surface in contact-mode scratching. In this case, pits preferentially initiated at the matrix/Al-Cu-Fe-Mn interface where local anodic and cathodic sites could be simultaneously activated. The scratching experiment also suggests that the repassivation by chromate ions of scratched areas is a fast and efficient process because no long-range interactions between individual $\mathrm{Al}-\mathrm{Cu}-\mathrm{Fe}-\mathrm{Mn}$ and $\mathrm{Al}_{2} \mathrm{CuMg}$ particles (a few micrometers apart) have been observed.

\section{Conclusions}

AFM and SKPFM were successfully used to locate and identify heterogeneities in AA2024-T3 samples. Upon exposure to various electrolytes, the evolution of the surface was monitored using topographic and Volta potential maps. The following observations were made.

1. For large exposed areas $\left(>1 \mathrm{~cm}^{2}\right)$, pits originated at $\mathrm{Al}_{2} \mathrm{CuMg}$ intermetallic particles in sodium chloride solutions under open-circuit conditions.

2. The local nobility of some $\mathrm{Al}_{2} \mathrm{CuMg}$ particles with respect to the matrix was reversed after refreshing the surface by sputter etching the surface film. The particles dissolved upon subsequent exposure to chloride solution, and they left behind a $\mathrm{Cu}$-rich layer that exhibited high Volta potentials.

3. The OCP of the alloy was in good agreement with Volta potential changes and was pinned to the potential of the most active sites. In the presence of dichromate, no pitting was observed even for long exposure times. Under applied potential (up to $-600 \mathrm{mV} \mathrm{SCE}$ ), no pit was observed in the area of investigation below the probe.

4. Light AFM scratching of the surface in $0.5 \mathrm{M} \mathrm{NaCl}+10^{-4} \mathrm{M} \mathrm{Na}_{2} \mathrm{Cr}_{2} \mathrm{O}_{7}$ resulted in 
the formation of pits on the perimeter of $\mathrm{Al}-\mathrm{Cu}-\mathrm{Fe}-\mathrm{Mn}$ particles that spread into the adjacent matrix.

5. Noble $\mathrm{Al}-\mathrm{Cu}-\mathrm{Fe}-\mathrm{Mn}$ inclusions are active cathodic sites and drive pit initiation around them. As the area ratio of these particles increases with respect to the surrounding exposed area, the pitting mechanism dramatically changes from the dissolution of $\mathrm{Al}_{2} \mathrm{CuMg}$ inclusions to attack of the matrix.

6. No attack was seen at areas that contained only Al-Cu-Fe-Mn particles or no Al-CuFe-Mn particles; both local anodes and cathodes were required for localized attack to occur.

7. Certain large $\mathrm{Al}_{2} \mathrm{CuMg}$ particles corroded without the presence of $\mathrm{Al}-\mathrm{Cu}-\mathrm{Fe}-\mathrm{Mn}$ cathodes, leaving a high potential $\mathrm{Cu}$-rich remnant. However, such remnants did not become active cathodes and drive pitting of neighboring regions as their reducing power is much less than that of $\mathrm{Al}-\mathrm{Cu}-\mathrm{Fe}-\mathrm{Mn}$ intermetallics.

8. Dichromate ions form a strong protective film on $\mathrm{Al}_{2} \mathrm{CuMg}$ and $\mathrm{Al}-\mathrm{Cu}-\mathrm{Fe}-\mathrm{Mn}$ inclusions, preventing both cathodic reactions and anodic dissolution.

\section{Acknowledgments}

This work was supported by the United States Air Force Office of Scientific Research under contract no. F49620-96-1-0479. Dr. Valerie Laget is gratefully acknowledged for her help with the AES sputtering work.

The Ohio State University assisted in meeting the publication costs of this article.

\section{References}

1. I. L. Muller and J. R. Galvele, Corros. Sci., 17, 179 (1977).

2. J. R. Galvele and S. M. DeMicheli, Corros. Sci., 10, 795 (1970).

3. Y. V. Murty, T. Z. Kattamis, and O. Devereux, Corrosion (Houston), 31, 207 (1975).

4. R. Ambat and E. S. Dwarakadasa, J. Appl. Electrochem., 24, 911 (1994).

5. K. Sugimoto, K. Hoshino, M. Kageyama, S. Kageyama, and Y. Sawada, Corros. Sci., 15, 709 (1975).

6. T. J. Warner, M. P. Schmidt, F. Sommer, and D. Bellot, Z. Metallkd, 86, 494 (1995).

7. C. Blanc, B. Lavelle, and G. Mankowski, Corros. Sci., 39, 495 (1997).

8. J. O. Park, C. H. Paik, Y H. Huang, and R. C. Alkire, J. Electrochem. Soc., 146, 517 (1999).

9. R. G. Buchheit, J. Electrochem. Soc., 142, 3994 (1995).

10. K. Urushino and K. Sugimoto, Corros. Sci., 19, 225 (1979).

11. R. G. Buchheit, R. P. Grant, P. F. Hlava, B. McKenzie, and G. L. Zender, J. Electrochem. Soc., 144, 2621 (1997).

12. P. Schmutz and G. S. Frankel, J. Electrochem. Soc., 145, 2295 (1998).

13. P. Schmutz and G. S. Frankel, J. Electrochem. Soc., 145, 2285 (1998).

14. P. Schmutz and G. S. Frankel, J. Electrochem. Soc., 146, 4461 (1999).

15. R. M. Rynders, C. H. Paik, R. Ke, and R. C. Alkire, J. Electrochem. Soc., 141, 1439 (1994).

16. K. Kowal, J. DeLuccia, J. Y Josefowicz, C. Laird, and G. C. Farrington, J. Electrochem. Soc., 143, 2471 (1996).

17. T. Suter and R. C. Alkire, J. Electrochem. Soc., 148, B36 (2001).

18. V. Guillaumin and G. Mankowski, Corros. Sci., 41, 421 (1999).

19. A. Kolics, A. S. Besing, and A. Wieckowski, J. Electrochem. Soc., 148, B322 (2001).

20. V. Guillaumin, P. Schmutz, and G. S. Frankel, J. Electrochem. Soc., 148, B163 (2001). 